\title{
COMMENT
}

\section{Goodbye, Columbus}

\author{
Gregory A Petsko*
}

The throne room of the Spanish court in Madrid, some time in the late 15th century. Seated side by side are King Ferdinand and Queen Isabella. Standing before them is a tall, muscular man wearing the clothes of a sea captain, holding his hat in his hands. He speaks Spanish, but with a pronounced Italian accent.

Ferdinand: Now who's next? Oh, yes, Captain Columbus. I assume you're here to appeal the decision about your proposal.

Columbus: Yes, Your Majesties. I don't understand why my request for support was turned down.

Isabella (leafing through some documents): Let's see, let's see - oh, here it is. 'Finding a New Route to the Indies by Sailing West.' (Looking up at him) You're serious, right? I mean, this isn't some sort of joke...

Columbus: Of course it's no joke! I propose to test the hypothesis that the world is both small and round. If the hypothesis is true, I should be able to reach the Orient much faster than the current route around Africa.

Ferdinand: And if the hypothesis is wrong, you'll fall off the edge of the earth.

Columbus: Possibly. But even if it's wrong, by going where no one has gone yet, I might bump into something really interesting.

Ferdinand: What you'll bump into is the edge of the earth, and you'll fall off.

Columbus: I agree that there is risk involved, Your Majesty, but consider the impact if I'm right. In the guidelines for obtaining funding, you specify that impact is a major factor in determining if a proposal is funded.

Isabella: I know we say that, Captain, but we don't mean it. Why, if we actually judged proposals that way, many of them would fail.

Ferdinand: That's right, Liz. I mean, think of how it would look if we funded something that didn't pan out.

Columbus: But then, what criteria do you use?

Isabella: Oh, we don't decide these things ourselves, Captain. Your proposal was peer-reviewed. Let's see (shuffles through more papers), here we are. Oh, my. Your priority score was really terrible.

*Correspondence: petsko@brandeis.edu

Rosenstiel Basic Medical Sciences Research Center, Brandeis University, Waltham, MA 02454-9110, USA
Columbus: Yes, I know that, but why?

Isabella: Well, the summary statement says that the Voyages of Discovery Study Section found your proposal too unlikely to succeed. For one thing, there were not enough preliminary data to indicate it was sure to work.

Columbus: But your guidelines say that a lot of preliminary data aren't required for proposals of high potential impact!

Ferdinand: And you believed that? Ha ha ha ha! What an idiot!

Isabella: Now, Ferdie. Don't be too harsh. But he's right, you know, Captain. Study Sections have to be sure a project will succeed before they recommend we fund it.

Columbus: But how can you be sure something will work unless you've already done it?

Isabella: That's exactly the point. Once you've already accomplished all your Specific Aims, people know it's safe to fund you to try to accomplish them.

Columbus (feeling dizzy): But where am I supposed to get the money to do that?

Ferdinand: That's not our problem. Money is so tight these days that we can't fund anything that isn't guaranteed to work. I mean, what if the Inquisition found out we were wasting money?

Columbus: But you have to have some failures if you're doing anything innovative or creative. New ideas don't always work.

Ferdinand: Well, they won't get funded, then.

Columbus: But what sort of ideas do you fund if you don't fund hypothesis-testing?

Isabella: Oh, big data-gathering projects that are certain to produce data, even if the data aren't very valuable. Fra Pedro de la Vega's project to count all the olive trees in Spain, for example, and put them in numerical sequence. The Olive Tree Sequencing Project.

Columbus: But what good is that?

Ferdinand: Beats me. But it's guaranteed to work, and besides, we already have all those trained counters from his successful Grape Vine Sequencing Project and his famous Flamenco Dancer Sequencing Project. Have to keep them working, you know.

Isabella: The other thing we fund is incremental research. Study Sections love incremental research. Nothing is as risk-free as people just doing more of what they've already been doing.

Ferdinand: Yes, I remember now. That was another criticism of your proposal: it's way too ambitious. You 
shouldn't be trying to reach the Indies all at once. Now if you had proposed to sail west to, say, Portugal...

Columbus: But that's ridiculous! Everybody knows that Portugal is immediately west of Spain. Of course you can get there by sailing west. What will you learn from that?

Isabella: Not much, if anything. But it can't fail, now, can it? Besides, you've sailed to Portugal before, so the Study Section would know you can do it.

Ferdinand: Yes, your problem, you see, was in proposing to do something that no one has done before. People who hope to get funded don't do that any more. You shouldn't try to be daring and unique. Just follow what everyone else is doing.

Columbus: Then there would be no more big discoveries, no overturning false beliefs, no radical change. What sort of world would we have without them?

Isabella: A predictable one.

Columbus: I refuse to believe that a collection of my peers would think that way. May I see the list of the people who were on the review panel, Your Majesty? (The Queen hands him a sheet of paper; he looks down at it) But - but - I don't recognize anyone on this list! Where are the other great explorers and navigators, the ones who could appreciate what I'm trying to do?

Ferdinand: Well, we tried to get Vasco da Gama and Freddy Magellan to serve, but they claimed they were too busy with their own voyages to take the time to be on the panel.

Columbus: But this critique is unreasonable.

Isabella: Don't blame us, Captain. Blame your fellow explorers. If the science of exploration is becoming too conservative and ideas like yours can't get funded, it's not the fault of administrators like us. It's the fault of your own community. After all, you review each other's proposals. You're a victim of what the Good Book says in Matthew 10:36, 'And a man's foes shall be they of his own household.'

Ferdinand: Liz, I'm impressed. Quoting the King James Bible, and King James won't even be born for a couple of hundred years or so.

Isabella (blushing): I also see here in the Summary Statement that the panel felt your budget was just too inflated. Asking for three ships! They say you should be able to manage fine with just one - the Pinta, say.

Columbus: Your Majesties, no one undertakes a voyage of discovery with just one ship. If anything goes wrong, you would be stranded.

Ferdinand: Well, there you go. See, that's your whole problem: you don't understand that the possibility that something could go wrong is just not acceptable anymore. Things have to be risk-free now.

Isabella (kindly): I'm sure this is disappointing for you, Captain, but the criticisms in this statement are very constructive, and I think after this conversation you should be able to revise your proposal so that it has a much better chance of being funded the next time.
Ferdinand: Yes, just reduce your budget to one ship, propose an easily achievable Specific Aim like discovering Lisbon, and accumulate enough preliminary data by actually going to Lisbon so the panel can be certain you know how to get there. Then there's a very good chance you will get the money you ask for, and you can use it to go even farther than you propose.

Isabella: That's right. With funding like that, you might actually reach, oh, I don't know, maybe the western suburbs of Lisbon. Wouldn't that be wonderful!

Ferdinand: You run along, now, Captain, and start working on that revised application. You just missed the next deadline, I'm sorry to say, but there will be another one in 6 months, so if you're successful the next time, you ought to be able to get started by early 1494 or so. Follow what everyone else is doing, and you'll be fine.

(Head down, Columbus slowly walks away. After he is out of the throne room, the King turns to his consort)

Ferdinand: Well, Liz, what do you think?

Isabella: I'm not sure, Ferdie. What if he's right? What if the world is small and round and you really can sail -

Ferdinand: Preposterous! Everybody knows that's not true. Imagine, paying good money just on the off-chance conventional wisdom might be wrong.

Isabella: But if there's even a small chance... I mean, think of the impact. Maybe we should have taken some money and let him try.

Ferdinand: What, and go against peer review? Think of the grief we'd get. It's so much safer for us, too, not to take any chances. The Inquisition is happy, you and I are happy -

Isabella: Yes, but maybe instead of everybody always following in the same direction like sheep, we ought to let some people with new ideas try to lead us somewhere else for a change.

Ferdinand: Nonsense. Look, no more talk about Captain Columbus. I guarantee you that in a few years no one will even remember his name.

Isabella (sighing): All right. Then let's look at this proposal for a completely new big initiative, one that we can fund ourselves. It's a proposal from Don Hernando Gonsalvo to look for very small changes in the amount of water that one finds in cisterns, accumulate as much data as possible, and attempt to connect it with something interesting.

Ferdinand: Something interesting like what?

Isabella: He doesn't say. He just says all that data will certainly tell us something.

Ferdinand: Ah yes, I remember that proposal now. The Gonsalvo Water Association Study. GWAS. Catchy. I like it. Now that's real science!

Published: 18 May 2012

doi:10.1186/gb-2012-13-5-155

Cite this article as: Petsko GA: Goodbye, Columbus. Genome Biology 2012 13:155. 